\title{
IDŐJÁRÁS
}

Quarterly Journal of the Hungarian Meteorological Service

Vol. 125, No. 2, April-June, 2021, pp. 271-290

\section{Air pollution in Ukraine: a view from the Sentinel-5P satellite}

\author{
Mykhailo Savenets \\ Ukrainian Hydrometeorological Institute \\ 37 Nauky Prospect, 03028, Kyiv, Ukraine \\ savenetsm@gmail.com
}

(Manuscript received in final form April 6, 2020)

\begin{abstract}
The study presents analysis of current air pollution state over Ukraine including remote regions and uncontrolled Ukrainian territories; features of $\mathrm{NO}_{2}, \mathrm{SO}_{2}$, and $\mathrm{CO}$ spatial distribution and seasonality under the influence of local anthropogenic emissions. The research is based on Sentinel-5P satellite data for the period of November 2018 - January 2020. Despite the increasing traffic emissions, the industrial emissions still greatly influence the air pollution in Ukraine. Sentinel-5P coverage allowed detecting a number of cities with huge anthropogenic $\mathrm{NO}_{2}$ and $\mathrm{SO}_{2}$ emissions, where ground-based measurements are absent. Uncontrolled territories on the east part of Ukraine still negatively affect air quality in the region due to the activity of coal-fired thermal power plants. The study indicates significant air quality changes during the heating season in winter and open burning in March - April. There were found differences in $\mathrm{NO}_{2}$ seasonal variability over clean remote regions and industrial zones. The paper analyzes features of shipping emissions during the tourist season for Ukrainian coastline of Black and Azov Seas, showing huge negative impact of chaotic movements of tourists boats near the Dzharylhach National Nature Park.
\end{abstract}

Key-words: Sentinel-5P, air pollution, seasonality, emissions, nitrogen dioxide, sulfur dioxide, carbon monoxide

\section{Introduction}

Open data development significantly increases the public awareness of air quality in Ukraine. Nowadays it becomes the concern of not only scientists and ecologists, but also ordinary people. Nevertheless, the state monitoring network for atmospheric air quality is still not developed well. Recently, Ukraine started the process of implementation of air quality EU Directives (Bashtannik et al., 2016), and huge steps have been done by the authorities. However, the state monitoring network is the remnant of the former Soviet Union, where most sites 
were set close to the location of emission sources without orientation to the territories with the highest population density. Currently, only 37 cities are carrying out ground-based measurements. Not so long ago, the air quality monitoring network covered 53 cities, but Ukraine lost a number of them on uncontrolled territories (on the Crimea and partially in the Donetsk and Luhansk regions) due to the Ukrainian - Russian conflict.

The above mentioned coverage by monitoring network gives the possibility to analyze air pollution in large cities and over industrial regions. However, a general picture of air quality over the entire country is absent. Therefore, the overwhelming majority of research in Ukraine contain the results only for cities, where state monitoring sites exist (Bashtannik et al., 2014; Savenets et al., 2018; Shevchenko et al., 2016; Yatsenko et al., 2018). Very little amount of air pollution research had been done for Ukraine using satellite data (Dvoretska, 2007; Galytska et al., 2018; Milinevsky et al., 2014) which often were corresponded to the territory with available ground-based measurements.

Over the globe, satellite data provide great vision of air quality, pollutants' distribution, temporal variability, etc., (Ghude et al., 2013; Krotkov et al., 2016; Lamsal et al., 2013; Richter et al., 2011). Sentinel-5P launch with TROPOMI instrument on it revolutionized remote sensing of air quality and showed new opportunities for satellite data usage, allowing distinguishing air pollution of separate cities (Ialongo et al., 2020; Zheng et al., 2019). In 2019, Sentinel-5P data were firstly used in Ukraine for the study of main features in pollutants' spatial distribution over the country, which showed tremendous differences in our knowledge about the most polluted areas (Savenets et al., 2020). Many of the polluted territories have not been mentioned before as problematic regions. The Ukrainian coastline unexpectedly appeared as rather polluted area, firstly indicating the necessity of atmospheric air pollution analysis over the Black and Azov Seas, especially since the problem of ship emissions is not new for Europe (Aulinger et al., 2016).

Great challenge appeared in 2014-2015, after the interruption of measurements on uncontrolled Ukrainian territories, where real atmospheric air quality became unknown. The situation seems to be serious on the east part of Ukraine as the territory is industrially loaded and there are no official information about the current industrial activity. The uncontrolled part of the Donetsk region is highly populated, which means the high probability of that the thermal power plants and local factories continue working. Thermal power plants and coal consumption have the greatest influence on the sulfur dioxide $\left(\mathrm{SO}_{2}\right)$ anthropogenic emissions (Jiang et al., 2019), thus the absence of state control and management pose a risk for air quality in the region. Moreover, numerous military equipments from both sides protect the border and influence the environment and atmospheric air quality specifically. Changes of economic development have direct effect on pollutants' emissions (Sinha, 2016). In these conditions, satellites become the only sources of monitoring the atmospheric 
chemicals data providing vital information for the analysis of air pollution over the uncontrolled territories.

The present study aimed to define air pollution state for the entire Ukrainian territory including remote regions and uncontrolled territories, to deepen the knowledge about seasonal changes of pollutants and to better understand spatiotemporal variability over Ukraine under the local anthropogenic load.

\section{Data and methods}

The research was carrying out using Sentinel-5P TROPOMI data for column number density of three pollutants: nitrogen dioxide $\left(\mathrm{NO}_{2}\right)$, carbon monoxide (CO), and sulfur dioxide $\left(\mathrm{SO}_{2}\right)$. The selected pollutants are enough for describing the features of air quality in Ukraine, because all main emission sources contain at least one of these chemical species. A large amount of data needed to be processed, because the main task is dedicated to air quality analysis in Ukraine, and total period covers more than one year. In this case, one of the most suitable instruments for analysis is the Google Earth Engine. It allows quickly processed data over Ukraine for relatively long period. The first full month in the Google Earth Engine available for all selected pollutants is November 2018, therefore the total research period covers 15 months: November 2018 - January 2020. The selected period gives the opportunity to look through the ongoing air pollution situation in Ukraine and to detect main features of seasonal changes.

Data processing were implemented in Earth Engine Code Editor using JavaScript. The original data are represented as Level 2 products, whereas Google Earth Engine converts them to Level 3 products, where data is binned by latitude/longitude, not by time. Data were filtered with quality assurance index 0.5 during the conversion; however, information might be used attentively to avoid false conclusions. Overall, temporal or spatial averaging usually offset unreliable data if any of them exist after filtering.

For general air quality estimation averaging for the entire research period was used. Air pollution analysis during particular cases and seasons implemented with averaging for the periods from several days to several months depends on the research purpose and duration of impact from emission source. In case of shipping pollution, average $\mathrm{NO}_{2}$ data significantly smooth the main patterns, therefore, maximal values better represent spatial distribution of $\mathrm{NO}_{2}$ pollution from shipping.

Total column derived from Sentinel-5P cannot be accurately recalculated to near-ground values, which are crucial for estimation of negative air pollution influence on human health and ecosystems. Approximate near-ground values could be calculated using some assumptions about the vertical distribution of pollutants and knowing its molar mass. The overwhelming majority of $\mathrm{NO}_{2}, \mathrm{CO}$, 
and $\mathrm{SO}_{2}$ molecules over industrial regions and big cities gathered in the troposphere. Let us suppose, that the pollutant distributes in the lower $10 \mathrm{~km}$ layer $(H)$, and its concentrations $(C)$ are equal on each altitude for more simple calculations. $\left[\mathrm{mol} / \mathrm{m}^{2}\right]$ must be converted to $\left[\mathrm{mg} / \mathrm{m}^{3}\right]$ for comparison with national threshold standards. Therefore, the near-ground value in $\left[\mathrm{mg} / \mathrm{m}^{3}\right]$ is:

$$
C=\frac{C_{c o l}}{H} \cdot M \cdot A,
$$

where $C_{c o l}$ is the pollutant column content $\left[\mathrm{mol} / \mathrm{m}^{2}\right], M$ is the molar mass [g/mol], $A$ is a constant, equals to 1000 , for conversion from $\left[\mathrm{g} / \mathrm{m}^{3}\right]$ to $\left[\mathrm{mg} / \mathrm{m}^{3}\right]$. $H$ is expressed in [m].

It has to be clarified that the recalculated near-ground concentrations were comparable to the usual in-situ values, however, with lower-than-expected values. It happens because of assumption about pollutants' equal vertical distribution. However, during the analysis of heating season, even recalculated values exceed national threshold standards; therefore, the author deems it necessary to describe the formulae in favor of heating season case analysis.

\section{Results and discussions}

\subsection{General features of air pollution in Ukraine}

Ukraine had been developed as the mix of an industrial and agricultural country for more than the 50 years. Such development significantly affects the current air pollution levels and features of pollutants' spatial distribution. After the Soviet Union had collapsed, the industry in Ukraine rapidly decreased due to the huge economic crisis, and many factories were closed. Nevertheless, there are five big industrial zones in Ukraine, which are located close to mines or cities with working industrial units.

The most well-known region is Donbass situated on the east part of Ukraine. Donetsk and Luhansk administrative regions comprise most factories and mines, however, Ukrainian - Russian conflict interrupted the production on the most uncontrolled territories. Another big industrial zone located near the Dnipro River in the central part of Ukraine. There are also a powerful set of factories near Kyiv city, on the northeast near Kharkiv city, and close to the Carpathians.

In the last decade the traffic continuously increased, which caused rather serious trouble in big cities like Kyiv, Kharkiv, Odesa, Dnipro, Lviv, etc. Some drivers use cars, which do not filter the exhaust properly. Roads in the city centers, bypass routes within suburbs, and roads for commuting going out from cities are the busiest with traffic during day hours. Elevated pollution levels due to traffic emissions appear in case of favorable weather conditions with slow wind speed and temperature inversions. 
Despite a large number of stationary point and linear emission sources, the square under agriculture is also big. These territories are typically low-emission zones during the year. However, the practice of agricultural burning is popular in Ukraine, therefore, in early spring and autumn, short-term but huge amount of substances from biomass burning are emitted in the atmosphere.

Talking about Ukrainian territories three regions must be mentioned: Polissia (the north part of Ukraine), the Carpathian Mountains, and the Crimean Mountains. These regions are the cleanest in Ukraine, where number of natural reserves and parks are situated. In 1986, after the Chernobyl Nuclear Power Plant explosion, the population from the closest territories had been resettled, making the Polissia region even less populated.

$\mathrm{NO}_{2}$ column number density is the most appropriate parameter for estimation of atmospheric air quality in Ukraine, which allowed distinguishing polluted zones and typical background. The highest $\mathrm{NO}_{2}$ column number density was observed over Kyiv and number of industrial cities in the Donbass region: Sloviansk, Kramatorsk, Khartsyzk, Kostiantynivka, Kurakhove, Novyi Svit. Kyiv combines huge emissions from traffic and industry, whereas traffic is not the main problem of Donbass cities. As in European cities, traffic emissions become the greatest issue, while industrial emissions continue to prevail over the tabove mentioned regions with high $\mathrm{NO}_{2}$ content. Average $\mathrm{NO}_{2}$ column number density over mentioned cities exceed $1.2 \cdot 10^{-4} \mathrm{~mol} / \mathrm{m}^{2}$ (Fig. 1).

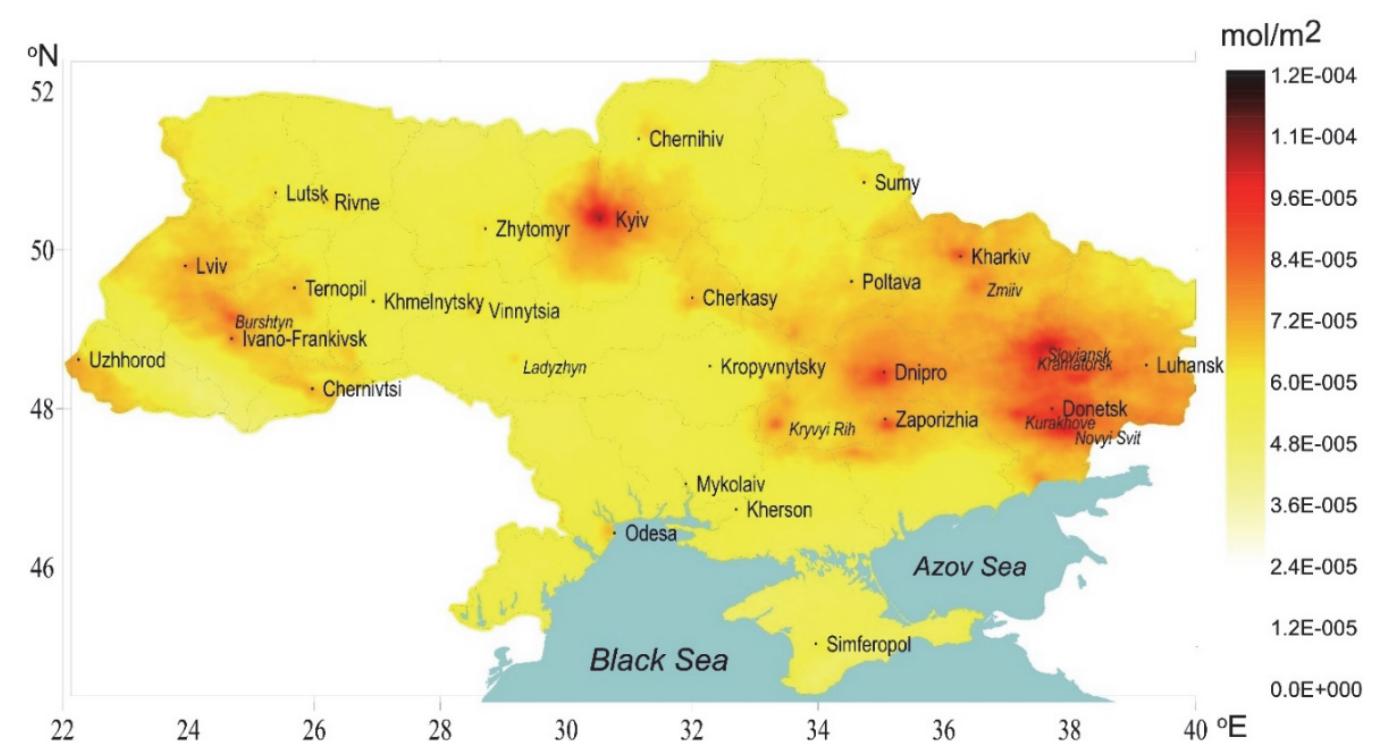

Fig. 1. Spatial distribution of average $\mathrm{NO}_{2}$ column number density for November 2018 January 2020. 
Thermal power plants are the main pollution sources over the Donbass region. The challenge is to estimate air pollution on uncontrolled Ukrainian territories on the east, where monitoring sites stopped in-situ measurements, and industry do not provide any information about current emissions. In this situation, remote sensing became the key opportunity for air pollution monitoring over uncontrolled territories. Using Sentinel-5P data huge $\mathrm{NO}_{2}$ emissions were detected over Novyi Svit, where Starobeshiv thermal power plant is located. It becomes clear, that power plant is operating at full capacity, and emissions might significantly exceed permissible levels.

Except for the group of cities with the highest $\mathrm{NO}_{2}$ content, there are another two groups, where air pollution levels are high and the average $\mathrm{NO}_{2}$ column number density reaches about $1.0-1.2 \cdot 10^{-4} \mathrm{~mol} / \mathrm{m}^{2}$. The first group of big cities, which are the centers of administrative regions, has high $\mathrm{NO}_{2}$ content due to traffic and industrial emissions: Kharkiv, Lviv, Odesa, Dnipro, Zaporizhzhia, Cherkassy, and others. The other group of relatively small towns, where thermal power plants emit $\mathrm{NO}_{2}$, contains, e.g., Burshtyn, Ladyzhyn, Zmiiv.

The rest territory on the distance from industrial zones and big cities is rather clean with background $\mathrm{NO}_{2}$ column number density of about 4.0-7.0 $10^{-5}$ $\mathrm{mol} / \mathrm{m}^{2}$. Minimal $\mathrm{NO}_{2}$ concentrations observed over Carpathians Mountains, Crimean Mountains, and Polissia on the north part of Ukraine, where average values usually do not exceed $4.0 \cdot 10^{-5} \mathrm{~mol} / \mathrm{m}^{2}$.

The spatial distribution of average $\mathrm{CO}$ column number density over Ukraine is quite homogeneous. The reason of it is the longer lifetime in the atmosphere, therefore, $\mathrm{CO}$ can distribute on the longer distances. As a result, any significant differences in spatial distribution are smoothed. There are four cities with values exceeding $4.0 \cdot 10^{-2} \mathrm{~mol} / \mathrm{m}^{2}$ : Mariupol (the highest $\mathrm{CO}$ content in Ukraine), Dnipro, Zaporizhzhia, and Kryvyi Rih. The main pollution sources in these cities are numerous factories and power plants. Average background CO column number density over Ukraine is about $3.0 \cdot 10^{-2} \mathrm{~mol} / \mathrm{m}^{2}$. The cleanest territories are the Carpathians and Crimean Mountains, where average CO column number density do not exceed $2.0 \cdot 10^{-2} \mathrm{~mol} / \mathrm{m}^{2}$.

The spatial distribution of $\mathrm{SO}_{2}$ is highly heterogeneous in contract to that of $\mathrm{CO}$. Therefore, analysis makes sense only for relatively large territories, not for particular point locations. Main $\mathrm{SO}_{2}$ emission sources in Ukraine are metallurgical industry and coal-running power plants. In general, the most polluted area is southeastern Ukraine, where the most industrial sources are located. The average $\mathrm{SO}_{2}$ column number density over these regions often exceed $3.0 \cdot 10^{-4} \mathrm{~mol} / \mathrm{m}^{2}$. There is only one point in Ukraine, where strong $\mathrm{SO}_{2}$ emissions are observed during the year. This point is the previously mentioned Novyi Svit with Starobeshiv thermal power plant, situated on the uncontrolled Ukrainian territory, where the average $\mathrm{SO}_{2}$ column number density exceeds $4.6 \cdot 10^{-4} \mathrm{~mol} / \mathrm{m}^{2}$. 


\subsection{Seasonal variability and meteorological impact}

Ukraine is one of the largest countries in Europe with a total area of 603628 $\mathrm{km}^{2}$ having both remote clean territories and polluted industrial regions with huge anthropogenic emissions. Analysis of $\mathrm{NO}_{2}$ column number density over Ukraine allows detecting two types of seasonal variations that significantly differ. Over clean remote regions, which are plains on the north and mountains on the west parts of the country, the summertime $\mathrm{NO}_{2}$ content is higher than the wintertime. Industrial regions and big cities do not have clear seasonality, however, frequent elevated pollution levels during December - February disrupt the distribution, and winter average values are always higher than in other months.

$\mathrm{NO}_{2}$ intra-annual variations in remote regions have seasonal maxima from late May to June, when column number density reach $0.7-0.8 \cdot 10^{-4} \mathrm{~mol} / \mathrm{m}^{2}$ (Fig. 2). From March to November, $\mathrm{NO}_{2}$ values are characterized by small variance, and concentrations form under local conditions with rarely visible impact from cities and polluted areas. In winter, the $\mathrm{NO}_{2}$ content decreases to about $0.4-0.6 \cdot 10^{-4} \mathrm{~mol} / \mathrm{m}^{2}$. Nevertheless, the highest $\mathrm{NO}_{2}$ values ever observed in clean regions appeared in winter on the background of low values. It happened due to cases with polluted air advection from cities and industrial zones. These cases usually are short-term and lasts only few days, however, they disrupt the typical $\mathrm{NO}_{2}$ seasonality. This is the reason why we could observe maximal $\mathrm{NO}_{2}$ concentrations in the cold season, whereas, usual $\mathrm{NO}_{2}$ content due to natural processes is the lowest. The highest $\mathrm{NO}_{2}$ column number density exceeds $2.0 \cdot 10^{-4} \mathrm{~mol} / \mathrm{m}^{2}$, which is typical for large, highly polluted cities.

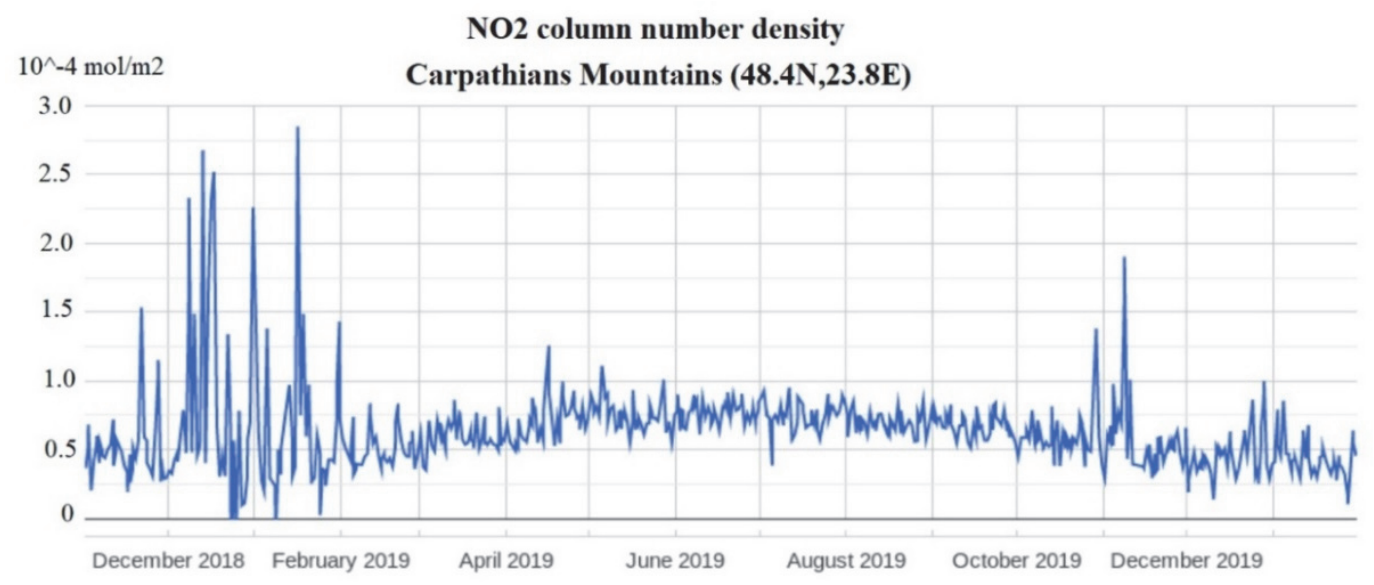

Fig. 2. $\mathrm{NO}_{2}$ column number density over the Carpathian Mountains for November $2018-$ January 2020. 
$\mathrm{NO}_{2}$ in cities and industrial regions has opposite variations with maximal content from December to February, because the weather conditions are favorable for pollutants' accumulation, car engines are running cold, and additional emissions appear from heating. $\mathrm{NO}_{2}$ column number density in winter often exceed 3.0 $10^{-}$ ${ }^{4} \mathrm{~mol} / \mathrm{m}^{2}$, the variance of data is high, and the polluted atmospheric air sometimes moved on long distances reaching clean regions. The most stable conditions are observed from June to August and slightly vary within $0.9-1.1 \cdot 10^{-4} \mathrm{~mol} / \mathrm{m}^{2}$ (Fig. 3).

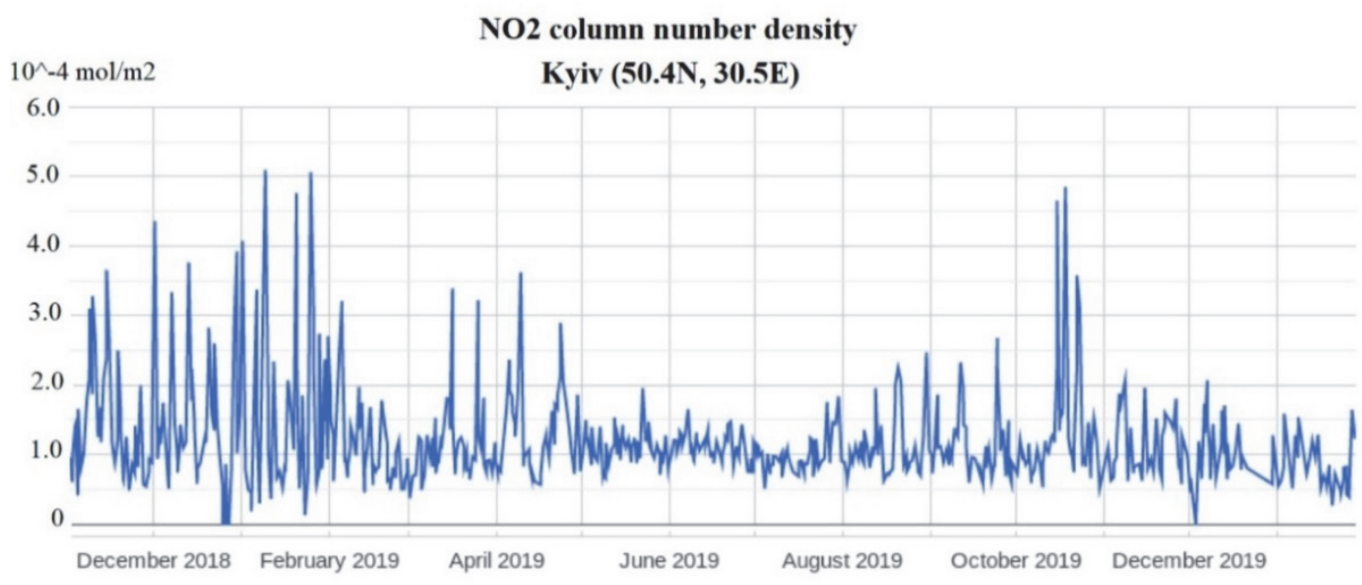

Fig. 3. $\mathrm{NO}_{2}$ column number density over Kyiv for November 2018 - January 2020.

CO seasonal variations over Ukraine are similar for the clean and highly polluted regions. Unlike $\mathrm{NO}_{2}$, it happens due to its longer lifetime in the atmosphere, and $\mathrm{CO}$ is rather equally distributed over the territory. Usually there are higher $\mathrm{CO}$ column number density from December to April reaching of about $3.0-4.0 \cdot 10^{-2} \mathrm{~mol} / \mathrm{m}^{2}$ in cities and polluted industrial zones (Fig. 4). Concentrations are lower over clean regions reaching about $2.7-3.5 \cdot 10^{-2} \mathrm{~mol} / \mathrm{m}^{2}$ (Fig. 5).

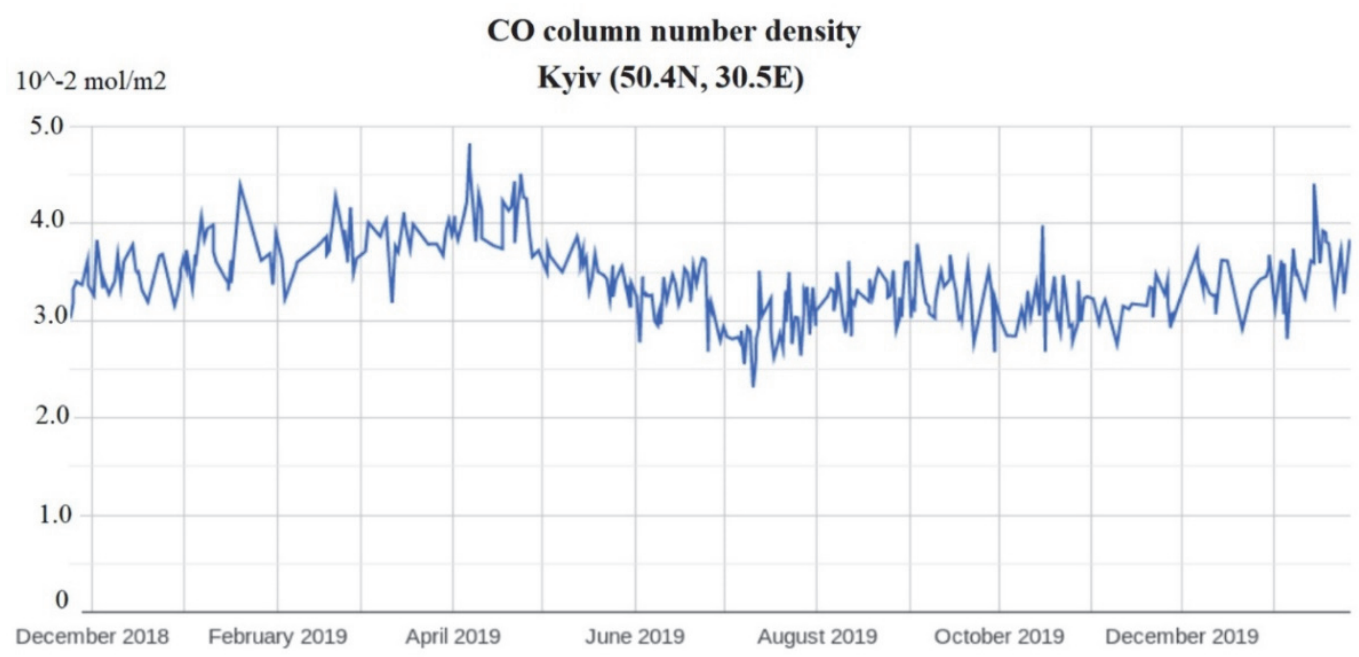

Fig. 4. CO column number density over Kyiv for November 2018 - January 2020. 


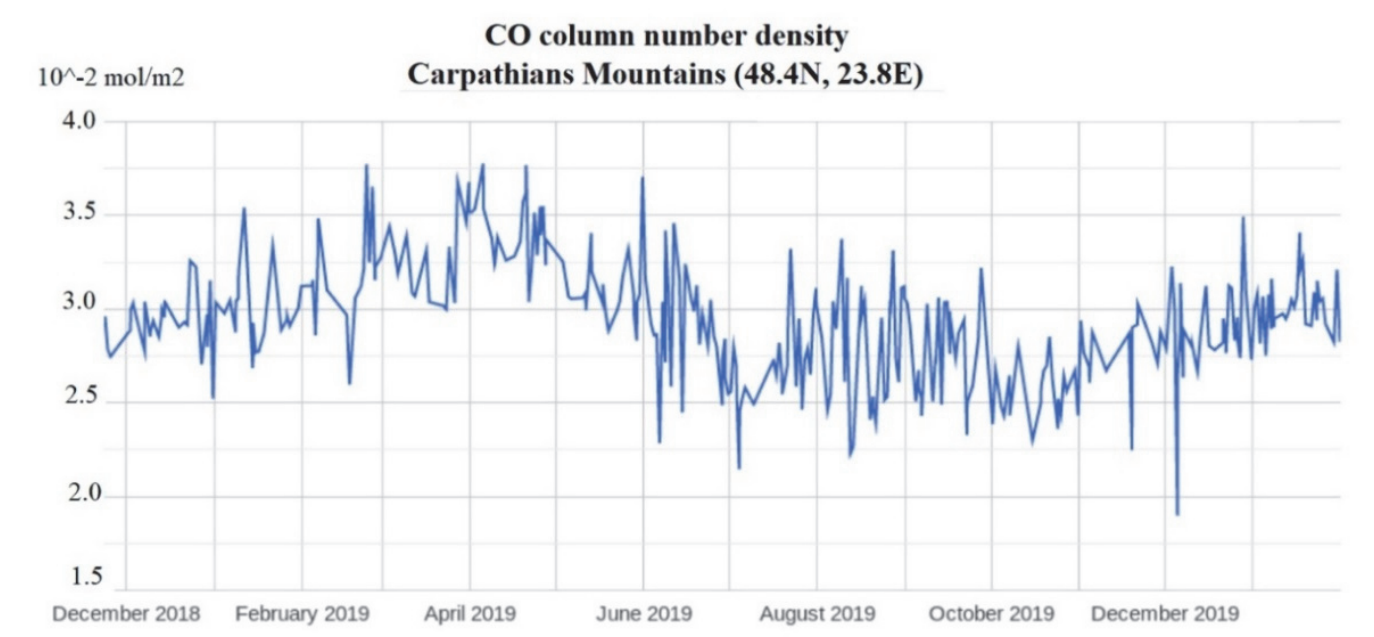

Fig. 5. CO column number density over the Carpathian Mountains for November 2018 January 2020.

CO intra-annual changes are well explained by the intensity of anthropogenic sources. Concentrations are gradually increasing in the start of heating season, from November to March, when the CO column number density is $1.0-1.5 \cdot 10^{-2} \mathrm{~mol} / \mathrm{m}^{2}$ higher than during the warm period. However, maximal values very often appear in April, which is completely out of the ordinary distribution, because heating season usually ends by this time, and the anthropogenic load decreases from February to March due to higher air temperatures. The answer about CO maximum in April is connected to the features of agricultural land usage in Ukraine. At the end of March - beginning of April, the weather conditions become stable with constant temperature increase and absence of raining. The snow usually disappears and the land under the sunny weather gets dry enough. Open burning still is very popular among Ukrainian farmers and on the private vegetable gardens. As the result of favorable weather conditions, most fields in Ukraine are being burnt at the end of March and in April, and huge amount of combustion products including CO are emitted in the air. This is the main reason, why we observed April CO maximum instead of gradually decreasing values.

As it can be seen in Figs. 4 and 5, the CO maxima in April is detected over clean and polluted regions. Moreover, the difference between spring months and winter months is higher in clean regions, because industrial zones have more $\mathrm{CO}$ emission sources that smooth the temporal distribution.

The CO content accumulated in the atmosphere during February - April decreases in May and usually minimal values are observed in July - the warmest month in Ukraine. From August to November, the $\mathrm{CO}$ column number density varies within $2.9-3.5 \cdot 10^{-2} \mathrm{~mol} / \mathrm{m}^{2}$ over the most polluted regions; in the 
Carpathian Mountains - the cleanest region in Ukraine -it varies from $2.5 \cdot 10^{-2}$ $\mathrm{mol} / \mathrm{m}^{2}$ to $2.7 \cdot 10^{-2} \mathrm{~mol} / \mathrm{m}^{2}$.

Through the air pollution in Ukraine mostly depends on the anthropogenic emission sources meteorological conditions also have rather big influence on pollutants' seasonality. Air mass advection with elevated pollution levels originated from the cities and industrial zones very often change the background concentrations and its spatial distribution. One of the examples is represented in Fig. 6, when huge amount of $\mathrm{NO}_{2}$ was distributed from large cities to Carpathian Mountains on December 12-13, 2018. This is exactly the case, when extremely high values disrupt typical $\mathrm{NO}_{2}$ seasonality over clean regions.

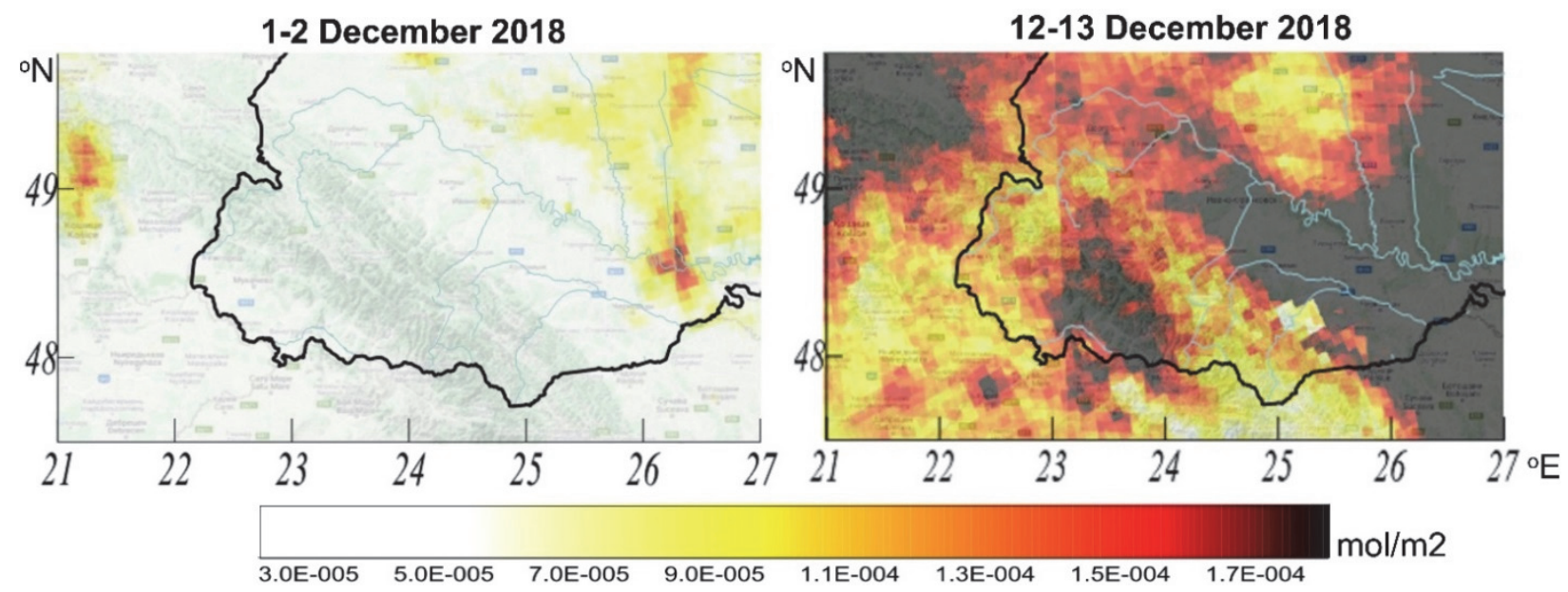

Fig. 6. $\mathrm{NO}_{2}$ column number density over western Ukraine and the Carpathians before December1-2, 2018 and during December12-13, 2018 a period of polluted air advection.

Meteorological conditions significantly influence air pollution levels through the possibility for pollutants' accumulation and removal. Moreover, the intensity of emissions often depends on temperature and wind regimes because of changes in industrial exploitation. Favorable synoptic situation may decrease concentrations to background levels even over large and industrial cities. The excellent example of positive weather influence on air pollution is the difference between $\mathrm{NO}_{2}$ column number density in January 2019 and January 2020 (Fig. 7). 


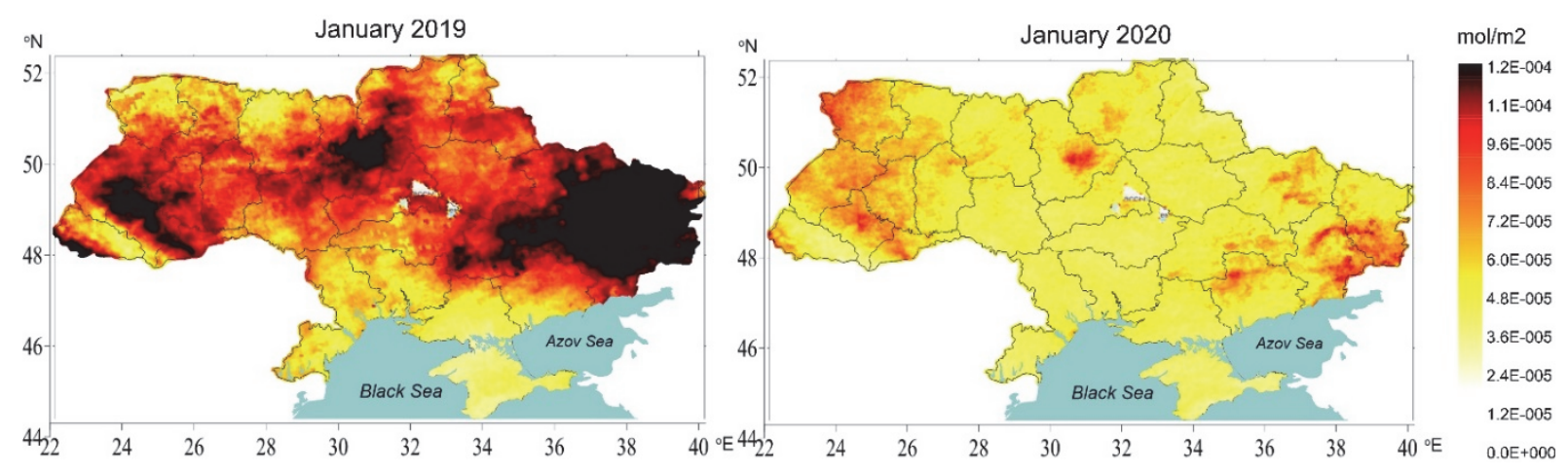

Fig. 7. Spatial distribution of average $\mathrm{NO}_{2}$ column number density in January 2019 and January 2020.

Temperature regime is the crucial difference between the winter months of 2019 and 2020. According to the Central Geophysical Observatory named after Boris Sreznevskiy $(C G O)$, January 2019 was a typical winter month for the Ukrainian territory (the coldest month in the year) with the average temperature of about $-4-5^{\circ} \mathrm{C}$, which was $1{ }^{\circ} \mathrm{C}$ higher than the climate normal. In contrast, January 2020 was extremely hot with abnormal average temperature over $0.5^{\circ} \mathrm{C}$, more than $6{ }^{\circ} \mathrm{C}$ higher than the climate normal. As a result, weather affected both the decreasing of emissions and the increasing of air pollutants' removal. In January 2019 , the power plants burned more fuel than in January 2020. The average $\mathrm{NO}_{2}$ column number density in January 2019 exceeded $1.0 \cdot 10^{-4} \mathrm{~mol} / \mathrm{m}^{2}$ over cities and adjacent territories, while in January 2020, it was lower than $8.0 \cdot 10^{-5}$ $\mathrm{mol} / \mathrm{m}^{2}$. Moreover, higher temperatures and frequent cloudless conditions have contributed to an increase of $\mathrm{NO}_{\mathrm{x}}$ chemical loss. Therefore, during the 20192020 winter, air pollution levels were low and $\mathrm{NO}_{2}$ concentrations were close to background values over the overwhelming majority of the territory.

\subsection{Tracking emissions from industrial point sources and wildfires}

There are a number of towns in Ukraine with relatively small area, rather low population, absence of busy traffic, but huge pollutants' emissions from industrial point sources. These features and the well-known origin of pollutants make them excellent objects for different kind of research dedicated to air pollution analysis, to study the dependence of plume distribution on different weather conditions, and to the comparison of satellite data with modeling results. However, most of the cities do not have any in-situ measurements, therefore, Sentinel-5P data might play crucial role for air quality monitoring and emissions tracking. The best examples of such type cities in Ukraine are Ladyzhyn, Burshtyn, Kurakhove, Novyi Svit, Chuhuiv, and Slobozhanske. Except Chuhuiv, all mentioned cities has powerful thermal power plants. 
Chuhuiv has several industrial emission sources close to each other. Novyi Svit is situated on the uncontrolled Ukrainian territory, therefore no information about real industrial capacities and emission inventories are available.

During favorable weather conditions, the plumes of elevated $\mathrm{NO}_{2}$ content were distributed from industrial sources affecting air quality in the relatively clean rural areas. Fig. 8 represents one of the cases with cloudless anticyclonic weather conditions and southwestern wind blowing for 4 days in one direction.

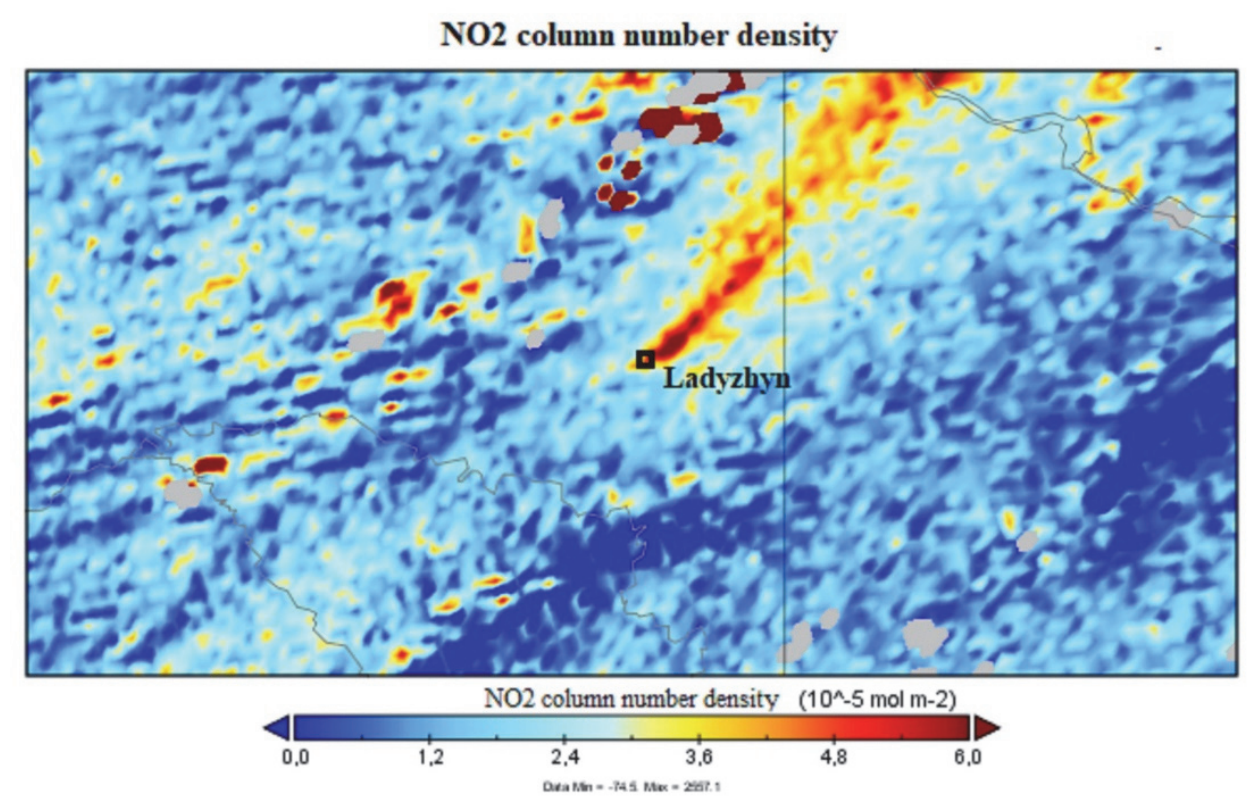

Fig. 8. $\mathrm{NO}_{2}$ column number density and the area affected by elevated pollution levels from industrial sources (August 8, 2019).

During August 4-9, 2019, an episode of stable anticyclonic weather condition was analysed which allowed to estimate the area affected by elevated $\mathrm{NO}_{2}$ content from thermal power plants. Total affected areas, where $\mathrm{NO}_{2}$ column number density could be recognized as plume, cover $200 \mathrm{~km}$ out from cities. On large distances, other sources smooth the clarity of $\mathrm{NO}_{2}$ plume, and it became impossible to detect the origin of the emissions.

Under the anticyclonic weather conditions with unidirectional 3-4 days wind, the affected area can be divided into 3 zones. At the distances up to 30 $\mathrm{km}, \mathrm{NO}_{2}$ column number density exceeds $5.0 \cdot 10^{-5} \mathrm{~mol} / \mathrm{m}^{2}$. Next zone usually covers the territory from of about 30 to $100 \mathrm{~km}$ out of the city, where $\mathrm{NO}_{2}$ column number density reaches $3.7-5.0 \cdot 10^{-5} \mathrm{~mol} / \mathrm{m}^{2}$ and the plume extends like a rather narrow strip. On the distances more than $100 \mathrm{~km}$, the plume is spreading, the $\mathrm{NO}_{2}$ content decreases to $2.0-4.0 \cdot 10^{-5} \mathrm{~mol} / \mathrm{m}^{2}$, however it is still well detected. Gradually, it becomes difficult to define whether the $\mathrm{NO}_{2}$ concentration is originated from an industrial point emission source or comes from other cities. 
The heating season is one of the most remarkable periods for air pollution increase in Ukraine. Usually it starts in November and lasts to March, however some deviations of its length are possible because of its relation to the transition of daily average air temperature through $8^{\circ} \mathrm{C}$ (Krakovska et al., 2019). Domestic heating has some differences in comparison with thermal power supply by power plants and heating stations. The usual period of domestic heating is longer; nevertheless, there might be weaker heating intensities during the cases of warmer weather conditions in winter.

Natural gas and coal are the mostly used fuels in Ukraine during the heating season. $\mathrm{CO}$ and $\mathrm{NO}_{2}$ emissions, which influence pollutants' concentrations often, cannot be tracked for this purpose by using Sentinel-5P data. $\mathrm{CO}$ lifetime is relatively big in comparison to the length of the heating season, therefore, it is equally distributed in different directions and no maximum appears on the average map for the winter season. $\mathrm{NO}_{2}$ has a large number of sources, which make possible to detect emissions during the heating season only in cities with huge power plants and rather small traffic intensity. In opposite to $\mathrm{CO}$ and $\mathrm{NO}_{2}$ concentrations, $\mathrm{SO}_{2}$ column number density gives great opportunity for monitoring air pollution in Ukraine from coal-fired power plants.

There are two big regions, where $\mathrm{SO}_{2}$ content significantly increase during the heating season due to usage of coal fuel in power plants. The first region is situated on the east part of Ukraine, where the majority of Ukrainian coal mines are located. The second region elongates from the northeast to the central regions of Ukraine. The maximum value of the $\mathrm{SO}_{2}$ content appears in the second region only during the heating season, which indicates prevailing of coal-fired heating plants, whereas the rest of the territory mainly uses natural gas for heating purpose. The average values of total $\mathrm{SO}_{2}$ column number density for heating season in cities with prevailing coal-burned power plants reach a level of about $2.2-4.0 \cdot 10^{-3} \mathrm{~mol} / \mathrm{m}^{2}$. If we suppose that the $\mathrm{SO}_{2}$ content gathered in the lower $10 \mathrm{~km}$ atmospheric layer, and for more easy calculations it is equally distributed within the mentioned layer, the near-ground average $\mathrm{SO}_{2}$ concentrations for three months are comparative to the daily $\mathrm{SO}_{2}$ threshold levels of $0.05 \mathrm{mg} / \mathrm{m}^{3}$ (threshold level according to the national standard $(C G O)$ ). Analysis showed that the mentioned two regions are highly affected by elevated $\mathrm{SO}_{2}$ levels due to coal burning during the heating season. Moreover, the region with elevated values on the east mostly is situated on the uncontrolled Ukrainian territory, which means problems during the implementation of European standards and air quality management. The rest territory of Ukraine does not have significant elevations of $\mathrm{SO}_{2}$ column number density with average values lower than $2.0 \cdot 10^{-4} \mathrm{~mol} / \mathrm{m}^{2}$.

The CO datasets from Sentinel-5P allow to detect elevated pollution levels caused by wildfires, moreover, averaging for several days makes visible the plume distribution from burned areas. Forests cover more than $15 \%$ of the 
Ukrainian territory, and the State Emergency Service of Ukraine (SESU) recorded about 96000 wildfires in 2019. With Sentinel-5P data it is possible to detect elevated pollution levels with $\mathrm{CO}$ from only the minority of forest fires, nevertheless, the largest reaches were always visible. During the large forest fires in Ukraine, $\mathrm{CO}$ average values for the period of active fire usually reach $4.5-5.0 \cdot 10^{-2} \mathrm{~mol} / \mathrm{m}^{2}$, whereas maximal column number density of about $0.15 \mathrm{~mol} / \mathrm{m}^{2}$. CO plumes from most fires usually extended to $100-150 \mathrm{~km}$ out from the source.

The analysis of elevated CO concentrations during wildfires showed an optimal period for appropriate disaster tracking using Sentinel-5P. Near real-time data and single data file might be good for indicating the position of maximal pollutants' concentration. However, very often it shows the plume which was transported at some distance, not the location of the exact emission source. Usage of single files, even with high quality assurance values, might cause false conclusions about the burned area. Averaging gives the opportunity to combine the plume distribution with the exact emission point using a series of the day-today files and to obtain a more complete picture. After averaging for different periods, it was found that 4-7 days are the optimal length for air pollution tracking. Periods of more than one week smooth the spatial values, thus plumes distribution and emission sources become less visible. Moreover, 4-7 days is the best period for staying within a single synoptic process in midlatitudes before another one appears significantly changing the direction of air advection and, consequently, the plume distribution.

\subsection{Shipping pollution}

Ukraine has access to the Black and Azov Seas with international seaports, active coastal shipping, numerous fishing boats and local cruise ships during the tourist season from June to September. It is worth to be noted, that the chaotic movement of fishing and tourist boats make impossible to estimate its exact amount. Big changes in Ukrainian shipping started in 2015, when the country lost control of Crimea during the Ukrainian - Russian conflict. Soon thereafter, shipping in Mariupol, Kherson, Mykolaiv, Odesa, and Chornomorsk has beenincreasingly congested. Tourists changed destinations, and the whole coastline of the Ukrainian mainland became a popular region for spending vacation.

All mentioned changes possibly caused the increasing of air pollution levels within the last 5 years; however, it is impossible to find any tendency due to the absence of in-situ measurements and coarse resolution of previous satellite missions. Currently, shipping pollution over sea and shoreline could be detected with Sentinel-5P data by using $\mathrm{CO}$ and $\mathrm{NO}_{2}$ datasets. Air quality is affected by the different ratios of chemical compounds depending on the petrol. There are some visible elevations of background $\mathrm{SO}_{2}$ levels over the sea; 
nevertheless, observed differences are not enough large to be considered as robust. The CO content is high along the shoreline of the Azov Sea, whereas it is not clearly visible over the Black Sea.

The analysis finds three main polluted areas because of intense shipping: the main trade routes the shorelines during the tourist season, and the river mouth of Pivdennyi Buh and Dnipro rivers. Over the mentioned areas, maximal values of $\mathrm{NO}_{2}$ column number density reach about $5.0-8.0 \cdot 10^{-4} \mathrm{~mol} / \mathrm{m}^{2}$ (Fig. 9).

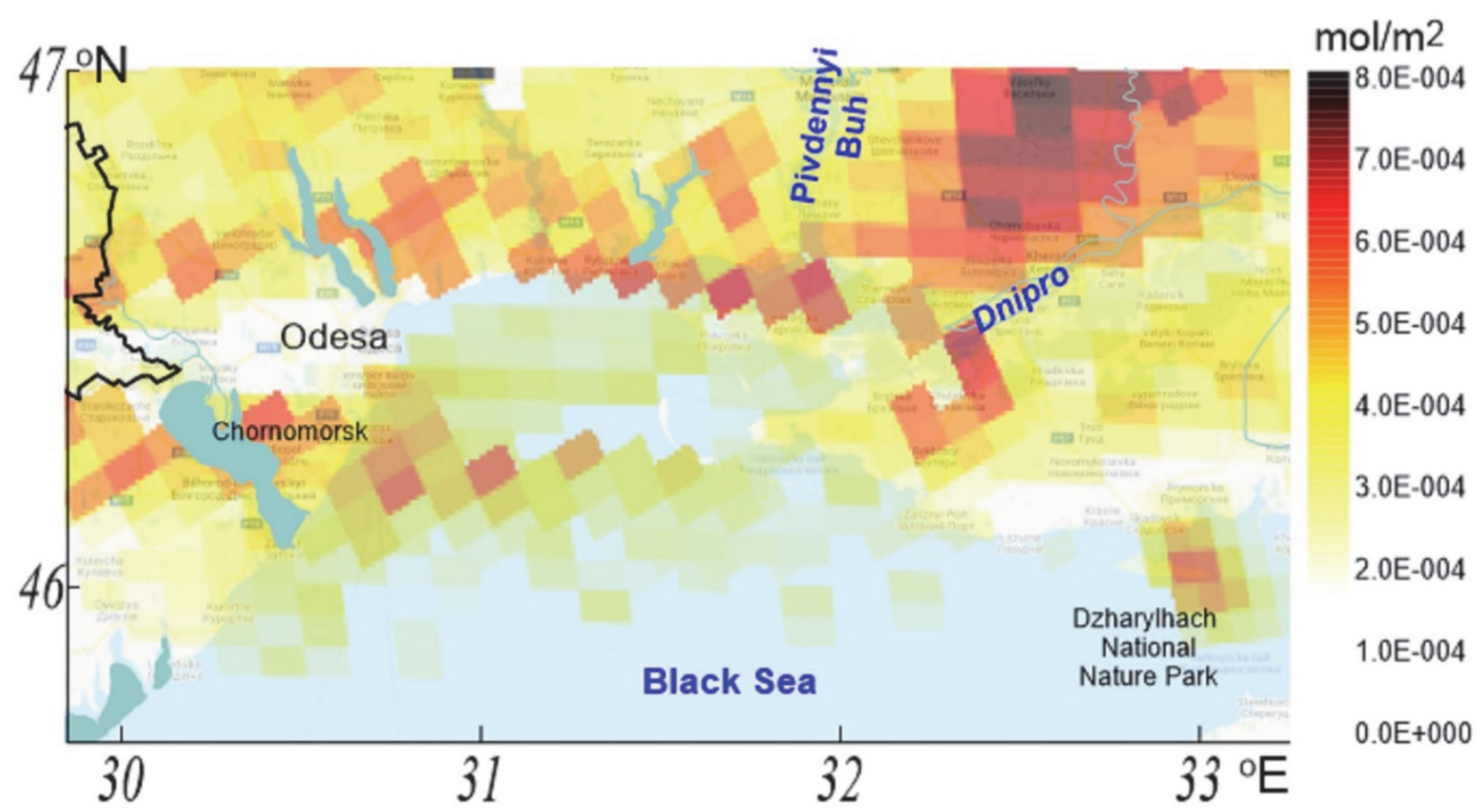

Fig. 9. Spatial distribution of maximal $\mathrm{NO}_{2}$ column number density values over the northwestern part of the Black Sea.

$\mathrm{NO}_{2}$ emissions is tracked by the main trade routes coming out of Odesa and Chornomorsk. Elevated $\mathrm{NO}_{2}$ total column values can be observed during the warm season and consist of several routes. Better-detected route connects to the opposite sides of the Ukrainian mainland, whereas the less visible routes are international routes to Bulgaria, Georgia, and Turkey.

The current study finds higher $\mathrm{NO}_{2}$ concentrations at the river mouth of Pivdennyi Buh and Dnipro, where local trade shipping prevails. The closer the sea is the higher $\mathrm{NO}_{2}$ content can be observed, which increases also by adding emissions from tourist boats near the popular beachside resorts on the way from Kherson and Mykolaiv river ports to the sea. Maximal values in the northwestern part of the Black Sea, where number of resorts are situated, exceed the $\mathrm{NO}_{2}$ background values: they are of about three times higher than over the 
sea at some distance from the coastline and twice higher than the inland $\mathrm{NO}_{2}$ content in that area.

The most unexpected results are obtained for the Dzharylhach National Nature Park, which is situated on the island Dzharylhach. The Park is popular among tourists, especially in its western part with two lighthouses and picturesque landscapes. During the active tourist season from June to August, $\mathrm{NO}_{2}$ concentrations significantly increase due to the numerous boats with hundreds of tourists arrive every day (Fig. 10).

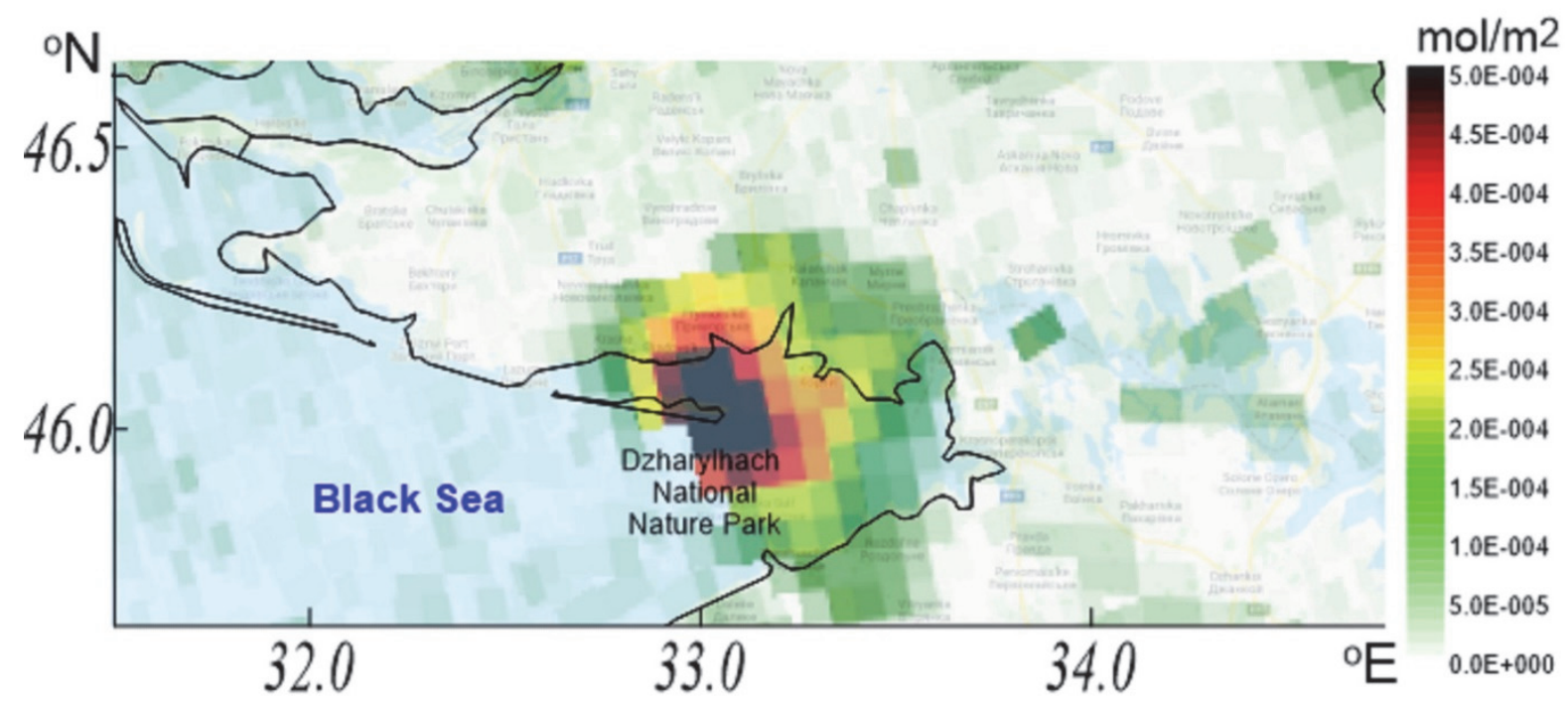

Fig. 10. Spatial distribution of maximal $\mathrm{NO}_{2}$ column number density values over the Dzharylhach National Nature Park (June 2019).

The problem of air pollution in the Park seems to be serious, as every day the $\mathrm{NO}_{2}$ column number density increases to $3.5-5.0 \cdot 10^{-4} \mathrm{~mol} / \mathrm{m}^{2}$ and spreads out from the island at an average distance of about $12-15 \mathrm{~km}$. The $\mathrm{NO}_{2}$ column number density over Dzharylhach during June-August is 5 times higher than concentrations over the surrounded mainland. However, control measures to the number of boats still have not been made.

\subsection{Discussions}

The absence of ground-based measurements in the highly polluted industrial cities caused lack of mention in previous research papers (Bashtannik et al., 2014; Savenets et al., 2018; Shevchenko et al., 2016; Yatsenko et al, 2018). These cities are Burshtyn, Khartsyzk, Kurakhove, Ladyzhyn, Novyi Svit, with an average $\mathrm{NO}_{2}$ column number density exceedeing $1.2 \cdot 10^{-4} \mathrm{~mol} / \mathrm{m}^{2}$, whigh is among the highest values in Ukraine. The mentioned cities need at least a 
development of a network with indicative measurements in the future. The current study showed that the affected area around these industrial cities could cover $200 \mathrm{~km}$ during the favorable weather conditions with unidirectional wind. All results in this study connected with industrial sources point the need to include the mentioned cities in each plan regarding air quality management in Ukraine.

Industrial zones on uncontrolled territories on the east part of Ukraine continue to contribute negative impact on atmospheric air. Several big power plants emit huge amount of $\mathrm{SO}_{2}$ and $\mathrm{NO}_{2}$. The current study confirms the findings from a previous one (Savenets et al., 2020), that emphasized on the mismatch between different sources of official and unofficial information and news. Sentinel-5P tracked highly polluted plumes from power plants on uncontrolled territories, which are the great evidence of its work at full or close to full capacities.

The great concern is the air quality along the coastline. Very often tourists visit resorts for recreation thinking about the benefits of marine air. Actually, the whole coastline during the tourist season is highly polluted due to the numerous boats. In fact, there are no regulations of small boats' movement, moreover information about atmospheric air pollution over the sea rarely appear among scientists and ecologists in Ukraine. Chaotic tourists' activity in the Dzharylhach National Nature Park over the last few years might became a real catastrophe for local ecosystems, which need more strict protection.

The study finds that anthropogenic emissions and features of agricultural land use significantly influence the CO seasonality over Ukraine. The wellknown fact is the role of $\mathrm{CO}$ loss due to $\mathrm{OH}$ concentrations decreasing in winter (Koike et al., 2006; Rinsland et al., 2000; Zhao et al., 2002). As a result, maximum values in the Northern Hemisphere can be observed in late winter/ early spring. The open burning activities during March - April in Ukraine result in a shift of the $\mathrm{CO}$ maxima to April, which means that $\mathrm{CO}$ temporal changes could not be explained only by anthropogenic emissions in winter and CO loss because of $\mathrm{OH}$. $\mathrm{CO}$ emissions during open burning is the main reason of that $\mathrm{CO}$ maximal values appear in April.

$\mathrm{SO}_{2}$ and $\mathrm{NO}_{2}$ seasonalities over cities depends on the location and emission sources, thus, they cannot be analyzed everywhere using similar methodology. In Ukraine, the highest $\mathrm{SO}_{2}$ concentrations are observed during the heating season because of fossil fuels usage for heating purpose. In comparison, $\mathrm{SO}_{2}$ seasonal changes might differ even taking into consideration European cities (Bralic et al., 2012).

\section{Conclusions}

Air pollution in Ukraine forms under the influence of traffic emissions and activity of the five biggest industrial zones. In most polluted cities, the average 
$\mathrm{NO}_{2}$ column number density exceeds $1.2 \cdot 10^{-4} \mathrm{~mol} / \mathrm{m}^{2}$, whereas background values are of about $4.0-7.0 \cdot 10^{-5} \mathrm{~mol} / \mathrm{m}^{2}$. There are three remote clean regions in Ukraine: the Carpathian Mountains, the Crimea Mountains, and Polissia with average $\mathrm{NO}_{2}$ column number density lower than $4.0 \cdot 10^{-5} \mathrm{~mol} / \mathrm{m}^{2}$. CO and $\mathrm{SO}_{2}$ contents are the highest over cities with numerous factories and coal-fired thermal power plants. Some of the most powerful emission sources are located on the uncontrolled Ukrainian territories, which are the evidence of its active work. Affected area with elevated pollution levels during the favorable weather conditions exceed $200 \mathrm{~km}$ out from industrial emission sources and $100-150 \mathrm{~km}$ during the wildfire events.

$\mathrm{NO}_{2}$ seasonal variations differ over clean remote regions and over industrial zones and cities. $\mathrm{NO}_{2}$ seasonal maxima can be observed in May - June over remote territories, whereas the highest values over cities occur during December - February. CO is the highest during December-March, which is the typical temporal distribution due to emissions increase and loss because of $\mathrm{OH}$ decreasing. However, in Ukraine the practice of open burning in late March April makes the maximum $\mathrm{CO}$ concentration to shift to April. $\mathrm{SO}_{2}$ seasonal variations depend on anthropogenic emission sources. In regions with coal-fired power plants, maximal values appear during the heating season.

During the tourist season, the coastline of Black and Azov Seas is five times more polluted than the nearest inland territories because of the uncontrolled chaotic movement of tourist and fishing boats. Maximal $\mathrm{NO}_{2}$ column number density reaches $5-8 \cdot 10^{-4} \mathrm{~mol} / \mathrm{m}^{2}$, even over the territory of the Dzharylhach National Nature Park that has become a popular visit point over the last few years.

Acknowledgements: The author is grateful for the help of the organizing committee and tutors of Trans-Atlantic Training 2019 (TAT-7, Novi-Sad, Serbia, 20-24.06.2019) "Radar and optical remote sensing in the agricultural and environmental monitoring" and to the First Joint Training Course on Atmospheric Composition (Cluj-Napoka, Romania, 04-08.11.2019) for receiving valuable knowledge and skills which allow to carry out the presented study.

\section{References}

Aulinger, A., Matthias, V., Zeretzke, M., Bieser, J., Quante, M., and Backes, A., 2016: The impact of shipping emissions on air pollution in the greater North Sea region - Part 1: Current emissions and concentrations. Atmos. Chem. Phys. 16, 739-758. https://doi.org/10.5194/acp-16-739-2016

Bashtannik, M.P., Dvoretska, I.V., Onos, L.M., and Savenets, M.V., 2016: Osnovni zasady vydilannia zon yiakosti atmosfernoho povitria na terytorii Ukrainy ta yih klasifikatsia zhidno z vymohamy dyrectyv 2004/107/EC ta 2008/50/EC. Naukovi pratsi UkrNDGMI 269, 123-137. (In Ukrainian) Баштаннік, М.П., Дворецька, І.В., Онос, Л.М., Савенець, М.В. 2016: Основні засади виділення зон якості атмосферного повітря на території України та їх класифікація згідно 3 вимогами директив 2004/107/ЕС та 2008/50/ЕС. Наукові праиі УкрНДГМІ 269, 123-137.

Bashtannik, M.P., Zhemera, N.S., Kiptenko, E.N., and Kozlenko, T.V., 2014: Stan zabrudnennia atmosfernogo povitria nad terytorieyu Ukrainy. Naukovi pratsi UkrNDGMI 266, 70-93. (In Ukranian) 
Баштаннік, М.П., Жемера, Н.С., Кіптенко, С.Н., Козленко, Т.В., 2014: Стан забруднення атмосферного повітря над територією України. Наукові пращі УкрНДГМI 266, 70-93.

Bralic, M., Buljac, M., Peris, N., Buzuk, M., Dabic, P., Brinic, S., 2012: Monthly and Seasonal Variations of $\mathrm{NO}_{2}, \mathrm{SO}_{2}$ and Black-smoke Located within the Sport District in Urban Area, City of Split, Croatia. Croat. Chem. Acta 85, 139-145. https://doi.org/10.5562/cca1966

CGO. Central Geophysical Observatory named after Boris Sreznevskiy. http://cgo-sreznevskyi.kiev.ua/index.php?lang=en

Dvoretska, I.V., 2007: Osnovni harakterystyky polya aerosoliy nad teritoriyeyu Ukrainy. Visnyk of V. N. Karazin Kharkiv National University, Series "Geology. Geography. Ecology 633, 120-131 Дворецька, I.B., 2007: Основні характеристики поля аерозолю над територією України. Visnyk of V. N. Karazin Kharkiv National University, Series "Geology. Geography. Ecology $633,120-131$

Galytska, E., Danylevsky V., Hommel, R., and Burrows, J.P., 2018: Increased Aerosol Content in the Atmosphere Over Ukraine During Summer 2010. Atmos. Measure. Tech. 11, 2101-2118. https://doi.org/10.5194/amt-11-2101-2018

Ghude, S.D., Kulkarni, S.H., Jena, C., Pfister, G.G., Beig, G., Fadnavis. S., and van der A, R.J., 2013: Application of satellite observations for identifying regions of dominant sources of nitrogen oxides over the Indian Subcontinent. J. Geophys. Res.: Atmospheres 118, 1075-1089 https://doi.org/10.1029/2012JD017811.

Ialongo, I., Virta, H., Eskes, H., Hovila, J., and Douros, J., 2020: Comparison of TROPOMI/Sentinel5 Precursor $\mathrm{NO}_{2}$ observations with ground-based measurements in Helsinki. Atmos. Meas. Tech. 13, 205-218. https://doi.org/10.5194/amt-13-205-2020

Jiang, J., Zhab, Y., and $\mathrm{Li}$, L., 2019: Simulation analysis of atmospheric $\mathrm{SO}_{2}$ contributions from different regions in China. Atmos. Pollut. Res. 3, 913-920. https://doi.org/10.1016/j.apr.2018.12.019

Koike, M., Jones, N.B., Palmer, P.I., Matsui, H., Zhao, Y., Kondo, Y., Matsumi, Y., and Tanimoto, H., 2006: Seasonal variation of carbon monoxide in northern Japan: Fourier transform IR measurements and source-labeled model calculations. J. Geophys. Res. 111, D15306. https://doi.org/10.1029/2005JD006643

Krakovska, S.V., Palamarchuk, L.V., and Shpytal, T.M., 2019: Climatic projections of heating season in Ukraine up to the middle of the 21st century. Geofizicheskiy Zhurnal 6(41), 144-164. https://doi.org/10.24028/gzh.0203-3100.v41i6.2019.190072

Krotkov, N.A., McLinden, C.A., Can Li, Lamsal, L.N., Celarier, E.A., Marchenko, S.V., Swartz, W.H., Bucsela, E.J., Joiner, J., Duncan, B.N., Boersma, K.F., Veefkind, P., Levelt, P.F., Fioletov, V.E., Dickerson, R.R., Hao He, Zifeng Lu, and Streets, D.G., 2016: Aura OMI observations of regional $\mathrm{SO}_{2}$ and $\mathrm{NO}_{2}$ pollution changes from 2005 to 2015. Atmos. Chem. Phys. 16, 4605-4629. https://doi.org/10.5194/acp-16-4605-2016

Lamsal, L.N., Martin, R.V., Parrish, D.D., and Krotkov, N.A., 2013: Scaling Relationship for $\mathrm{NO}_{2}$ Pollution and Urban Population Size: A Satellite Perspective. Environ. Sci. Technol. 47, 7855-7861. https://doi.org/10.1021/es400744g

Milinevsky, G., Danylevsky, V., Bovchaliuk, V., Bovchaliuk, A., Goloub, Ph., Dubovik, O., and Kabashnikov, V., 2014: Aerosol Seasonal Variations Over Urban-Industrial Regions in Ukraine According to AERONET and POLDER Measurements. Atmos. Meas. Tech. 7, 1459-1474. https://doi.org/10.5194/amt-7-1459-2014

Richter, A., Begoin, M., Hilboll, A., Burrows, J.P., 2011: An improved $\mathrm{NO}_{2}$ retrieval for the GOME-2 satellite instrument. Atmos. Meas. Tech. 4, 1147-1159. https://doi.org/10.5194/amt-4-1147-2011

Rinsland, C. P., Mahieu, E., Zander, R., Demoulin, P., Forrer, J., Buchmann, B., 2000: Free tropospheric $\mathrm{CO}, \mathrm{C}_{2} \mathrm{H}_{6}$, and $\mathrm{HCN}$ above central Europe: Recent measurements from the Jungfraujoch station including the detection of elevated columns during. J. Geophys. Res. 105, 24235-24249. https://doi.org/10.1029/2000JD900371

Savenets, M., Dvoretska, I., and Nadtochii, L. 2020: Current state of atmospheric air pollution in Ukraine based on Sentinel-5P satellite data. Visnyk of V. N. Karazin Kharkiv National University, Series Geology. Geography. Ecology 51, 221-233. 
Savenets, M., Nadtochii, L., and Dvoretska, I., 2018: $\mathrm{NO}_{2}$ seasonal and interannual variability in Ukrainian industrial cities. GeoScience Engineering, LXIV, 4, 29-36. https://doi.org/10.2478/gse-2018-0019

Shevchenko, O., Yatsenko, Y., and Danilova, N., 2016: Osoblyvosti chasovyh zmin koncentraciy formaldehidu $\mathrm{v}$ atmosfernomu povitri mist Ukrainy. Visnyk Kyivskogo Natsionalnogo Universytetu. Viiskovo-spetsialni nauky 2, 24-29.

Шевченко, О., Яценко, Ю., Данілова, Н., 2016: Особливості часових змін концентрацій формальдегіду в атмосферному повітрі міст України. Вісник Київського національного університету. Військово-спеиіальні науки 2, 24-29.(In Russian)

Sinha A., 2016: Trilateral association between $\mathrm{SO}_{2} / \mathrm{NO}_{2}$ emission, inequality in energy intensity, and economic growth: A case of Indian cities. Atmos. Pollut. Res. 4, 647-658. https://doi.org/10.1016/j.apr.2016.02.010

SESU: State Emergency Service of Ukraine. Wildfires statistics: https://undicz.dsns.gov.ua/ua/STATISTIKA-POZHEZH.html

Yatsenko, Y., Shevchenko, O., Snizhko, S., 2018: Otsinka suchasnogo rivnia ta tendencii zabrudnennia at-mosfernogo povitria mist Ukrainy dioksidom azotu. Visnyk of Taras Shevchenko National University of Kyiv: Geology 3(82), 87-95. https://doi.org/10.17721/1728-2713.82.11

Яиенко, Ю., Шевченко, О., Сніжко, С. 2018: Оцінка сучасного рівня та тенденцій забруднення атмосферного повітря міст України діоксидом азоту. Вісник Національного університету імені Тараса Шевченка: Геологія 3(82), 87-95. (In Russian)

Zhao, Y., Strong, K., Kondo, Y., Koike, M., Matsumi, Y., Irie, H., Rinsland, C.P., Jones, N.B., Suzuki, K., Nakajima, H., Nakane, H., and Murata, I., 2002: Spectroscopic measurements of tropospheric $\mathrm{CO}, \mathrm{C}_{2} \mathrm{H}_{6}, \mathrm{C}_{2} \mathrm{H}_{2}$, and $\mathrm{HCN}$, in northern Japan. J. Geophys. Res. 107, 4343. https://doi.org/10.1029/2001JD000748

Zheng, Z., Yang, Z., Wu, Z., and Marinello, F., 2019: Spatial Variation of $\mathrm{NO}_{2}$ and Its Impact Factors in China: An Application of Sentinel-5P Products. Remote Sens. 11, 1939.

https://doi.org/10.3390/rs11161939 